\title{
Morphology and taxonomic position of the bizarre Permian pachydomid bivalve Leinzia from Western Gondwana
}

\author{
Marcello G. Simões, Vitor B. Guerrini, Suzana A. Matos, and Rosemarie Rohn \\ Acta Palaeontologica Polonica 65 (2), 2020: 291-303 doi:https://doi.org/10.4202/app.00665.2019
}

The genus Leinzia is a typical member of the renowned Artinskian-Wuchiapingian (Permian) endemic bivalve fauna of the Passa Dois Group, Paraná Basin, Brazil. The extraordinary shells of Leinzia , characterized by a rostrum extending from the anterior cardinal margin led certain authors to regard them as bivalved arthropods (Spinicaudata). Due to the unusual morphology and typically poor preservation of the available specimens, the taxonomic position of Leinzia still remains obscure. Leinzia has been variously referred either to the Pterioida, the Crassatelloidea, the Sanguinolitidae, or the Megadesmidae, or to the Pholadomyida. Herein, based on a detailed review of the topotype material and description of newly found specimens of Leinzia from the Serrinha Member, Rio do Rasto Formation, southern Brazil, we shed light on the taxonomic position of this genus. The hinge of the right valve with its large, blunt, anteriorly inclined subumbonal tooth and corresponding socket in the left valve coupled with the absence of true lateral teeth indicate close affinities to Pyramus and Cowperesia. Thus, the data here strongly suggest a Pachydomidae (Edmondioidea) rather than a Crassatelloidea affinity for Leinzia. Conversely, Leinzia differs from all other known Pachydomidae due to its anteriorly rostrate and posteriorly elongated shell. Finally, detailed stratigraphic data indicate that the vertical distribution of Leinzia is constrained to the middle part of the Guadalupian Serrinha Member of the Rio do Rasto Formation.

Key words: Bivalvia, Pachydomidae, Megadesmidae, endemism, Guadalupian, Paraná Basin, Brazil.

Marcello G. Simões [profmgsimoes@gmail.com] (corresponding author) and Suzana A. Matos [sumatos.s@gmail.com], Institute of Biosciences, São Paulo State University, Botucatu campus, Botucatu, P.O. Box 510, 18618-689, Brazil. Vitor B. Guerrini [vbguerrini@gmail.com] and Rosemarie Rohn [rosemarie.rohn@unesp.br], Institute of Geosciences and Exact Sciences, São Paulo State University, Rio Claro campus, Rio Claro, 13506-900, Brazil. 
This is an open-access article distributed under the terms of the Creative Commons

Attribution License (for details please see creativecommons.org), which permits unrestricted use, distribution, and reproduction in any medium, provided the original author and source are credited.

FoF Full text $(1,603.1 \mathrm{kB})$ 